\title{
Pengaruh Kompensasi dan Motivasi terhadap Kinerja Karyawan pada PT. Pratama Mega Kencana
}

\author{
Dodi Prasada ${ }^{1}$, Lily Setyawati Kristianti ${ }^{2}$ \\ 1,2 Universitas Pamulang, Banten, Indonesia \\ E-mail: dosen02454@unpam.ac.id, dosen02521@unpam.ac.id
}

\begin{abstract}
Article Info
Abstract

Article History

Received: 2021-05-12

Revised: 2021-08-15

Published: 2021-08-20

This study aims to determine how much influence compensation has on employee performance, the effect of motivation on employee performance and the effect of compensation and motivation together on employee performance, the data analysis method used is regression analysis, coefficient of determination and simultaneous test, Based on the results of partial hypothesis testing ( $\left.t_{\text {test }}\right)$ the $t_{v a l u e}$ is 2.060 and a

Keywords: Compensation; Motivation;

Performance. significant value is 0.04 , while the $t_{\text {table }}$ value is 1.656 . Because $t_{\text {count }}>t_{\text {table }}(2,060>$ $1,656)$ and significant value $<0.05(0.04<0.05)$, it can be concluded that compensation partially has a positive and significant effect on employee performance. Based on the results of partial hypothesis testing $\left(t_{\text {test }}\right)$ the $t$-value is 2.926 and a significant value is 0.00 , while the $t_{\text {table }}$ value is 1.656 . Because $t_{\text {count }}>t_{\text {table }}(2,926>1,656)$ and significant value $<0.05(0.00<0.05)$, it can be concluded that motivation partially has a positive and significant effect on employee performance. Based on the results of simultaneous hypothesis testing ( $\mathrm{f}$ test) the fcount value is 13.007 and a significant value is 0.040 while the ftable value at the confidence level is 3.12. Because $f_{\text {count }}>f_{\text {table }}(13.007>$ $3.12)$ and significant value $<0.05(0.00<0.05)$, it can be concluded that the Compensation and Motivation variables together have a positive and significant effect on employee performance.
\end{abstract}

\begin{tabular}{l}
\hline Artikel Info \\
\hline Sejarah Artikel \\
Diterima: 2021-05-12 \\
Direvisi: 2021-08-15 \\
Dipublikasi: 2021-08-20
\end{tabular}

Kata kunci: Kompensasi; Motivasi; Kinerja.

\begin{abstract}
Abstrak
Penelitian ini bertujuan untuk mengetahui seberapa besar pengaruh kompensasi terhadap kinerja karyawan, pengaruh motivasi terhadap kinerja karyawan dan pengaruh kompensasi serta motivasi secara bersama-sama terhadap kinerja karyawan, metode analisis data yang digunakan adalah analisis regresi, koefisien determinasi dan uji simultan, Berdasarkan hasil pengujian hipotesis secara parsial (uji t) diperoleh nilai $t_{\text {hitung }}$ sebesar 2,060 dan nilai signifikan sebesar 0,04, sedangkan nilai $t_{\text {tabel }}$ adalah 1,656. Karena $t_{\text {hitung }}>t_{\text {tabel }}(2,060>1,656)$ dan nilai signifikan $<0,05(0,04<0,05)$, maka dapat disimpulkan bahwa Kompensasi secara parsial berpengaruh positif dan signifikan terhadap kinerja karyawan, berdasarkan hasil pengujian hipotesis secara parsial (uji t) diperoleh nilai $t_{\text {hitung }}$ sebesar 2,926 dan nilai signifikan sebesar 0,00, sedangkan nilai $t_{\text {tabel }}$ adalah 1,656. Karena $t_{\text {hitung }}>t_{\text {tabel }}(2,926>1,656)$ dan nilai signifikan $<0,05(0,00<0,05)$, maka dapat disimpulkan bahwa Motivasi secara parsial berpengaruh positif dan signifikan terhadap kinerja karyawan. Berdasarkan hasil pengujian hipotesis secara simultan (uji f) diperoleh nilai $f_{\text {hitung }}$ sebesar 13,007 dan nilai signifikan sebesar 0,040 sedangkan nilai $\mathrm{f}_{\text {tabel }}$ pada tingkat kepercayaan adalah 3,12 . Karena $f_{\text {hitung }}>f_{\text {tabel }}(13,007>3,12)$ dan nilai signifikan $<0,05(0,00<0,05)$, maka dapat disimpulkan bahwa variabel Kompensasi dan Motivasi secara bersama-sama berpengaruh positif dan signifikan terhadap kinerja karyawan.
\end{abstract}

\section{PENDAHULUAN}

Untuk dapat memberikan tenaga yang berkualitas, kinerja karyawan yang tinggi sangatlah diharapkan oleh perusahaan tersebut. Semakin banyak karyawan yang mempunyai kinerja tinggi maka produktivitas perusahaan secara keseluruhan akan meningkat sehingga perusahaan akan dapat bertahan dalam persaingan global. Kinerja karyawan yang tinggi bukanlah suatu kebetulan saja, tetapi banyak faktor yang mempengaruhi diantaranya pemberian kompensasi dan motivasi, Pemberian kompensasi kepada karyawan perlu mendapatkan perhatian lebih oleh perusahaan, kompensasi harus memiliki dasar yang kuat, benar dan adil, apabila kompensasi dirasakan tidak adil maka dapat menimbulkan rasa kecewa kepada karyawan, sehingga karyawan yang baik akan meninggalkan perusahaan, tidak hanya faktor pemberian kompensasi saja yang perlu 
diperhatikan oleh perusahaan guna menigkatkan kinerja karyawan, akan tetapi perusahaan harus memperhatikan faktor motivasi. Karyawan dapat melaksanakan tugasnya secara maksimum antara lain ditentukan oleh motivasi yang mendorong pegawai itu bekerja dengan tekun, serta disiplin yang diterapkan sehingga dapat tercapai tujuan perusahaan di bawah kepemimpinan yang dapat menciptakan suasana kondusif terhadap lingkungan kerja tersebut, berikut disampaikan beberapa teori yang dapat mendukung penelitian ini, diantaranya:

a) Manajemen Sumber Daya Manusia

Dalam suatu organisasi atau perusahaan peranan manajemen sumber daya manusia sangatlah penting. Hal ini karena tanpa sumber daya manusia, suatu organisasi tidak mungkin berjalan. Manusia merupakan penggerak dan pengelola faktor-faktor produksi lainnya seperti modal, bahan mentah, peratalatan, dan lain-lain untuk mencapai tujuan organisasi, Secara etimologis manajemen sumber daya manusia merupakan penggabungan dua konsep yang secara maknawiah memiki pengertian yang berbeda. Kedua konsep tersebut adalah manajemen dan sumber daya manusia. Sebagaimana dijelaskan di atas dapat disimpulkan secara singkat bahwa manajemen adalah suatu seni mengelola manusia mulai dari input, process di dalam organisasi, sampai output dan outcome yang diharapkan untuk mencapai tujuan telah ditetapkan oleh organisasi atau perusahaan.

Menurut Widodo (2015:2) menyatakan "manajemen sumber daya manusia dipandang sebagai peranan yang cukup penting di ranah industri, apa yang dilakukan oleh manajer SDM menggambarkan bagaimana aktifasi pengelolaan SDM di lingkungan Perusahaan", Suherman (2012:5), "sumber daya manusia didefinisikan sebagai seseorang yang memiliki berbagai keunggulan berupa kemampuan, keterampilan, dan keahlian, terkait serta profesionalisme yang diekspresikan dalam sikap dan perilaku yang didominasi oleh halhal yang sangat bermanfaat bagi dirinya maupun bagi lingkungannya", Tohardi (2015:12) menyimpulkan "sumber daya manusia adalah segala potensi yang ada pada manusia baik berupa akal pikiran, tenaga, keterampilan, emosi dan sebagainya yang dapat digunakan baik untuk dirinya maupun untuk organisasi atau perusahaan", Menurut Marihot Tua E.H dalam Sunyoto (2015:1) mengatakan bahwa "sumber daya manusia adalah keseluruhan penentuan dan pelaksanaan berbagai aktivitas, policy, dan program yang bertujuan untuk mendapatkan tenaga kerja, pengembangan, dan pemeliharaan dalam usaha meningkatkan dukungannya terhadap peningkatan efektivitas organisasi dengan cara yang secara etis dan sosial dapat dipertanggungjawabkan", Hasibuan (2014:10) menjelaskan bahwa "manajemen sumber daya manusia adalah ilmu dan seni mengatur hubungan dan peranan tenaga kerja agar efektif dan efisien membantu terwujudnya tujuan perusahaan, karyawan dan masyarakat".

Dari pendapat ahli tersebut penulis dapat menyimpulkan bahwa "manajemen sumber daya manusia merupakan aktivitas yang dilakukan dengan mendayagunakan manusia untuk menunjang tercapainya tujuan organisasi itu sendiri.Fokus utama manajemen sumber daya manusia adalah pengelolaan pegawai, yaitu mengarahkan perilaku pegawai bagi kepentingan perusahaan atau instansi".

b) Kompensasi

Kompensasi merupakan balas jasa yang diberikan oleh organisasi atau instansi kepada pegawai, yang dapat bersifat finansial maupun non finansial, pada periode yang tetap. Sistem kompensasi yang baik akan mampu memberikan kepuasan bagi pegawai dan memungkinkan organisasi atau instansi memperoleh, memperkerjakan dan mempertahankan pegawai, Menurut Suparyadi (2015:272) "kompensasi adalah keseluruhan imbalan yang diterima oleh karyawan sebagai penghargaan atas kontribusi yang telah diberikan kepada perusahaan, baik yang bersifat finansial maupun non finansial". Sedangkan menurut Hasibuan (2012:118) "kompensasi adalah semua pendapatan yang diterima karyawan yang berbentuk uang, barang langsung atau tidak langsung yang merupakan bentuk biaya yang harus dikeluarkan perusahaan dengan harapan memperoleh imbalan berupa prestasi kerja dari karyawan", Handoko (2012:155) berpendapat "kompensasi adalah segala sesuatu yang di terima para karyawan sebagai balas jasa untuk kerja mereka, kompensasi harus memiliki dasar yang logistik, rasional dan dapat di pertahankan". Sedangkan menurut Mathis Dan Jackson (2010:118) menjelaskan "Kompenasi merupakan faktor 
penting yang mempengaruhi bagaimana dan mengapa orang-orang bekerja pada satu organisasi dan bukan pada organisasi yang lainnya".

Dari pendapat ahli tersebut penulis dapat menyimpulkan bahwa "kompensasi adalah pendapatan yang diterima pagawai sebagai balas jasa atas kontribusinya terhadap pencapaian tujuan organisasi atau instansi", Bagi organisasi, kompensasi memiliki arti penting karena kompensasi mencerminkan upaya organisasi dalam mempertahankan dan meningkatkan kesejahteraan pegawai. Pengalaman menunjukan bahwa kompensasi yang tidak memadai dapat menurunkan kinerja, motivasi kerja, dan kepuasan kerja pegawai. Kompensasi ditinjau dari sudut pandang organisasi atau instansi merupakan unsur biaya yang dapat mempengaruhi kinerja organisai atau instansi. Sedangkan ditinjau dari sudut pandang pegawai merupakan unsur pendapatan yang dapat mempengaruhi gaya hidup, status, harga diri dan perasaan pegawai terhadap instansi dan selain itu juga merupakan alat manajemen bagi instansi untuk meningkatkan motivasi kerja, meningkatkan produktifitas dan mempengaruhi kepuasan kerja.

c) Motivasi

Peran manusia yang tersedia didalam perusahaan merupakan faktor utama untuk mencapai suatu tujuan perusahaan. Untuk menghendaki manusia agar sesuai dengan yang dikhendaki organisasi, maka harus dipahami motivasi manusia yang bekerja dalam organisasi tersebut, karena motivasi inilah yang menentukan perilaku orang-orang untuk bekerja, Motivasi menurut Kreitner dan Kinicki dalam Wibowo (2016:322), "motivasi merupakan proses psikologis yang membangkitkan dan mengarahkan prilaku pada pencapaian tujuan atau goal-directed behavior", Menurut Hadari Nawawi (2012:351) "motivasi adalah suatu kondisi yang mendorong atau menjadi sebab seseorang melakukan suatu perbuatan/kegiatan, yang berlangsung secara sadar", Menurut Malayu SP Hasibuan (2017:143) mengatakan bahwa "motivasi adalah Pemberian daya penggerak yang menciptakan kegairahan kerja seseorang, agara mereka mau bekerja sama, bekerja efektif dan terintegrasi dengan segala daya upaya untuk mencapai kepuasan", Robbins dalam Edy Sutrisno (2010:117) menyatakan "motivasi ialah suatu kerelaan berusaha seoptimal mungkin dalam pencapaian tujuan organisasi yang dipengaruhi oleh kemampuan usaha memuaskan beberapa kebutuhan individu", Menurut Mangkunegara (2015:93) "motivasi adalah kondisi yang menggerakan pegawai agar mampu mencapai tujuan dan motifnya".

Dari pendapat ahli tersebut penulis dapat menyimpulkan bahwa "motivasi merupakan unsur penggerak yang mendasari seseorang dalam melaksanakan pekerjaan. Kinerja karyawan didasari oleh bagaimana motivasi yang dimiliki karyawan tersebut untuk bekerja", Jika karyawan termotivasi untuk bekerja dengan baik, maka kinerja karyawan juga akan menjadi baik dan cenderung untuk meningkat.

d) Kinerja Karyawan

Setiap organisasi mengharapkan agar seluruh anggotanya didalam perusahaan menunjukan sebuah kinerja yang optimal dalam menunjang tercapainya sebuah tujuan yang telah ditetapkan sebelumnya. Oleh karena itu sebuah kinerja harus mendapatkan perhatian dari pihak manajemen bila hendak mencapai tujuan yang diharapkan, Menurut Mangkunegara (2015:67) bahwa "kinerja merupakan hasil kerja secara kualitas dan kuantitas yang dicapai oleh seseorang karyawan dalam melaksanakan tugas sesuai dengan tanggung jawab yang diberikan kepadanya", Menurut Bambang Kusriyanto (2010:55) mengemukakan "Kinerja karyawan adalah perbandingan hasil yang dicapai dengan peran serta tenaga kerja persatuan waktu", Menurut Wibowo (2010:7) "Kinerja adalah tentang melakukan pekerjaan dan hasil yang dicapai dari pekerjaan tersebut", Sedangkan menurut Prawiro Suntoro dalam Moh. Pabundu Tika (2012:121) "kinerja adalah hasil kerja yang dapat dicapai oleh seseorang atau sekelompok orang dalam suatu organisasi dalam rangka mencapai tujuan organisasi dalam periode waktu tertentu".

Dari beberapa pendapat ahli tersebut penulis menyimpulkan "kinerja adalah hasil dari kegiatan yang dilakukan oleh karyawan setelah dibatasi oleh waktu dan tujuan"., Kegiatan kerja tersebut harus dibatasi agar dapat diselsesaikan sesuai target yang ditentukan, dan tidak menyimpang dari tujuan perusahaan. Selain itu, agar kegiatan kerja dilakukan sesuai dengan standar dan 
prosedur, sehingga dapat berjalan secara efektif dan efisien, Indikator kinerja karyawan menurut Mangkunegara (2015:67), antara lain adalah: (a) Kualitas kerja adalah seberapa baik seorang karyawan mengerjakan apa yang seharusnya dikerjakan, (b) Kuantitas kerja adalah seberapa lama seorang pegawai bekerja dalam satu harinya. Kuantitas kerja ini dapat dilihat dari kecepatan kerja setiap pegawai itu masing-masing, (c) Pelaksanaan Tugas adalah seberapa jauh karyawan mampu melakukan pekerjaannya dengan akurat atau tidak ada kesalahan, (d) Tanggung jawab terhadap pekerjaan adalah kesadaran akan kewajiban karyawan untuk melaksanakan pekerjaan yang diberikan perusahaan.

Kinerja karyawan sangat penting untuk kesuksesan sebuah perusahaan secara keseluruhan sehingga pemilik bisnis membutuhkan karyawan yang mampu menyelesaikan pekerjaan secara efektif. Kinerja merupakan suatu potensi yang harus dimiliki setiap pegawai untuk melaksanakan setiap tugas dan tanggung jawab yang diberikan organisasi kepada pegawai. Dengan kinerja yang baik, maka setiap pegawai dapat menyelesaikan segala beban organisasi dengan efektif dan efisien sehingga masalah yang terjadi pada organisasi dapat teratasi dengan baik, Pratama mega kencana merupakan sebuah perusahaan swasta dibidang jasa cleaning service di Indonesia yang dikelola oleh PT. Pratama Mega Kencana dan berlokasi di kawasan Ruko Boulavard, Serpong BSD, Tangerang Selatan. Pratama mega kencana merupakan cabang usaha dari kelompok dari PT Riztekindo yang didirikan pada tahun 1999. Memiliki 586 orang karyawan yang bekerja diperusahaan tersebut dengan berbagai macam jabatan.

Manager PT. Pratama Mega Kencana memberi kompensasi berupa gaji, upah lembur, upah kerajinan, tunjangan kesehatan serta bonus jika perusahaan mencapai target diberikan dengan baik dan sesuai dengan aturan yang ada, sedangkan berdasarkan persepsi karyawan kompensasi terhadap pemberian upah lembur tidak sesuai dengan kesepakatan serta pemberian upah lembur yang tidak tepat waktu.Tidak hanya kompensasi yang diberikan, usaha pencapaian tujuan organisasi tidak terlepas dari bagaimana seorang pemimpin meningkatkan kinerja karyawannya melalui motivasi, karena pada dasarnya karyawan juga mempunyai kebutuhan dan keinginan yang berbeda. Pengaruh motivasi terhadap kinerja juga terlihat dari seseorang untuk melakukan sesuatu atas dasar keinginan yang kuat dari dalam diri orang tersebut. Hubungan antara sesesorang yang termotivasi dengan pencapaian kinerja memiliki nilai positif, artinya pegawai yang mempunyai motivasi tinggi cenderung memiliki kinerja yang tinggi dan sebaliknya mereka yang mempunyai motivasi rendah memungkinkan seseorang memiliki kinerja yang rendah. Sebagai manusia mereka tidak terlepas dari berbagai macam keinginan maupun kebutuhan yang mendorong mereka dalam mencapai tujuanya. Pemberian motivasi yang kurang dari pemimpin akan kesadaran dan kebutuhan karyawan berpengaruh terhadap rendahnya kinerja karyawan. Motivasi yang rendah dapat dilihat dari ketidakhadiran karyawan selama ia bekerja. Ketidakhadiran memiliki dampak negatif bagi suatu perusahaan yang berakibat pada kosongnya lini tenaga kerja.

PT. Pratama Mega Kencana adalah sebuah perusahaan jasa cleaning service yang terletak di Jl. Ruko Boulevard BSD. Tangerang Selatan, adalah perusahaan yang bergerak dibidang jasa cleaning secara umum, pemberian motivasi masih dirasakan kurang optimal tentunya berdampak pada kurang optimalnya kinerja karyawan yang mengakibatkan kurang semangatnya karyawan dalam melakukan pekerjaannya

Motivasi karyawan dalam bekerja pada PT. Pratama Mega Kencana, pimpinan kurang dapat membangkitkan motivasi karyawannya dengan dorongan, pujian maupun penghargaan yang di berikan kepada karyawan, kurang adanya pengarahan dari manajemen PT. Pratama Mega Kencana untuk kemajuan dan pengembangan karyawan serta komunikasi antar sesama karyawan cenderung kurang terjaga dengan baik, Hal ini bila tidak segera dilakukan tindakan maka akan berdampak buruk bagi pencapaaian tujuan perusahaan, untuk itu pemimpin perusahaan harus lebih memperhatikan pemberian motivasi yang ada di perusahaan agar karyawan dapat kembali bersemangat bekerja dan menunjukan kinerja yang baik dalam membantu tercapainya tujuan perusahaan, Kinerja karyawan pada PT. Pratama Mega Kencana, cenderung masih kurang dari target pencapaian kurangnya kualitas karyawan, menurunnya pelaksanaan tugas karyawan dan kurangnya tanggung jawab karyawan PT. Pratama Mega Kencana, menjadi salah satu pemicu menurunnya kinerja karyawan.

Berdasarkan uraian di atas, maka penulis tertarik untuk mengadakan penelitian dengan 
judul "Pengaruh Kompensasi dan Motivasi Terhadap Kinerja Karyawan Pada PT. Pratama Mega Kencana", dan ditetapkan beberapa tujuan dalam Penelitian ini diantaranya: (a) Untuk mengetahui pengaruh pemberian kompensasi terhadap kinerja karyawan PT. Pratama Mega Kencana, (b) Untuk mengetahui pengaruh motivasi terhadap kinerja karyawan PT. Pratama Mega Kencana, (c) Untuk mengetahui pengaruh pemberian kompensasi dan motivasi secara bersama-sama terhadap kinerja karyawan PT. Pratama Mega Kencana.

\section{METODE PENELITIAN}

Penelitian yang di lakukan untuk penulisan ini bersifat deskritif kuantitatif penelitian yang digunakan dalam penelitian ini adalah metode kuantitatif, Sugiyono (2014:13) "metode penelitian kuantitatif merupakan penelitian yang bertujuan untuk mengetahui pengaruh ataupun hubungan antara dua variabel atau lebih. Teknik pengambilan sampel dilakukan secara ran, pengumpulan data menggunakan instrumen penelitian, analisis data bersifat kuantitatif/statistik dengan tujuan untuk menguji hipotesisyang telah ditetapkan", Dalam penelitian ini, penulis deskriptif terbatas pada usaha mengungkapkan suatu masalah dan keadaan sebagaimana apa adanya, sehingga hanya merupakan penyingkapan fakta, dari penelitian deskriptif tersebut dapat di ketahui suatu atau kejadian yang menjadi permasalahan besarnya yang ada di lokasi penelitian. Demikian akan ditawarkan solusi yang diharapkan dapat menyelesaikan permasalahan tersebut dan pengolahan datanya bersifat kuantitatif.

Menurut Sugiyono (2013:119), populasi adalah wilayah generalisasi yang terdiri atas: obyek atau subyek yang mempunyai kualitas dan karakteristik tertentu yang ditetapkan oleh peneliti untuk dipelajari dan dikemudian ditarik kesimpulannya. sesuai dengan judul penelitian yaitu Pengaruh Motivasi Terhadap Kinerja Karyawan Pada PT. Pratama Mega Kencana, maka populasi penelitian ini adalah karyawan PT. Pratama Mega Kencana, dengan jumlah sebanyak 586 karyawan, Sugiyono (2012:80), sampel adalah bagian dari jumlah dan karakteristik yang dimiliki oleh populasi tersebut. Bila populasi besar, dan peneliti tidak mungkin mempelajari semua yang ada pada populasi, misalnya karena keterbatasan dana, tenaga dan waktu, maka peneliti dapat menggunakan sampel yang diambil dari populasi tersebut.
Dalam hal ini metode yang digunakan dalam pengambilan sampel yaitu menggunakan rumus solvin, Sampel adalah sebagian dari populasi. Sampel terdiri atas sejumlah anggota yang dipilih dari populasi sekarang. Sugiyono (2013:424). Sebagai peneliti dengan jumlah populasi yang cukup besar. Jumlah karyawan yang ada pada PT Pratama Mega Kencana yaitu 586 karyawan. Berdasarkan rumus tersebut jumlah sampel yang diperoleh penelitian ini dengan nilai presisi yang ditetapkan sebesar 10\%. Maka jumlah sempel pada penelitian ini adalah berjumlah 78 orang karyawan pada PT. Pratama Mega Kencana, Dalam pengumpulan data, penulis menggunakan dokumentasi dan penyebaran kuesioner dan setelah data terkumpul dianalisis dengan pengujian statistik dengan regresi, korelasi, determinasi dan pengujian hipotesis.

\section{HASIL DAN PEMBAHASAN}

Pembahasan ini untuk membuktikan hipotesis yang diajukan dalam penelitian ini, yakni untuk mengetahui pengaruh antara variabel bebas (kompensasi dan motivasi) terhadap kinerja karyawan, baik secara parsial maupun secara simultan serta untuk menguji hipotesis penelitian yang telah dikemukakan sebelumnya.

Tabel 1. Ringkasan hasil Analisis Regresi liner Berganda

\begin{tabular}{|c|c|c|c|c|c|c|}
\hline \multicolumn{7}{|c|}{ Coefficients $^{a}$} \\
\hline & \multirow[t]{2}{*}{ Model } & \multicolumn{2}{|c|}{$\begin{array}{l}\text { Unstandardize } \\
\text { d Coefficients }\end{array}$} & \multirow{2}{*}{$\begin{array}{c}\begin{array}{c}\text { Standa } \\
\text { rdized } \\
\text { Coeffici } \\
\text { ents }\end{array} \\
\text { Beta }\end{array}$} & \multirow[t]{2}{*}{$\mathrm{t}$} & \multirow[t]{2}{*}{ Sig. } \\
\hline & & B & $\begin{array}{l}\text { Std. } \\
\text { Error }\end{array}$ & & & \\
\hline \multirow[t]{3}{*}{1} & (Constant) & 16.610 & 4.569 & & 3.636 & .001 \\
\hline & Kompensasi & .264 & .128 & .240 & 2.060 & .043 \\
\hline & Motivasi & .323 & .110 & .340 & 2.926 & .005 \\
\hline \multicolumn{7}{|c|}{$\mathrm{R}=0.507$} \\
\hline \multicolumn{7}{|c|}{$\mathrm{R}^{2}=0.258$} \\
\hline \multicolumn{7}{|c|}{ F hitung $=13.780$} \\
\hline \multicolumn{7}{|c|}{ Sig. $=0.000$} \\
\hline
\end{tabular}

Hasil pada tabel data diatas, diperoleh pesamaan regresinya sebagai berikut:

\section{$Y=16,610+0,264 X_{1}+0,323 X_{2}$}

Dari persamaan tersebut dapat diambil kesimpulan bahwa:

1) Konstanta sebesar 16,610 artinya bahwa jika Kompensasi $\left(\mathrm{X}_{1}\right)$ dan Motivasi $\left(\mathrm{X}_{2}\right)$ bernilai 0 , maka Kinierja Karyawan (Y) nilainya sebesar 16,610 .

2) Koefisien regresi Kompensasi $\left(X_{1}\right)$ sebesar 0,264 menyatakan bahwa setiap penambahan $1 \%$ variabel Kompensasi $\left(\mathrm{X}_{1}\right)$ maka dapat 
meningkatkan Kinerja Karyawan sebesar 0,264 dengan asumsi variabel lain bernilai tetap.

3) Koefisien regresi Motivasi $\left(X_{2}\right)$ sebesar 0,323 menyatakan bahwa setiap penambahan 1\% variabel Motivasi $\left(\mathrm{X}_{2}\right)$ maka dapat meningkatkan Kinerja Karyawan sebesar 0,323 dengan asumsi variabel lain bernilai tetap.

Berdasarkan tabel diketahui bahwa nilai $R$ Square $\left(\mathrm{r}^{2}\right)$ sebesar 0,258 atau 25,8\%. Jadi dapat disimpulkan bahwa Kompensasi dan Motivasi mempengaruhi kinerja karyawan sebesar 25,8\% sedangkan sisanya sebesar $74,2 \%$ dipengaruhi faktor lain yang tidak digunakan dalam penelitian ini.

Berdasarkan hasil pengujian hipotesis secara parsial (uji t) diperoleh nilai $t_{\text {hitung }}$ sebesar 2,060 dan nilai signifikan sebesar 0,04, sedangkan nilai $t_{\text {tabel }}$ adalah 1,656. Karena $t_{\text {hitung }}>t_{\text {tabel }}(2,060>$ 1,656) dan nilai signifikan $<0,05(0,04<0,05)$, maka dapat disimpulkan bahwa Kompensasi secara parsial berpengaruh positif dan signifikan terhadap kinerja karyawan.

Berdasarkan hasil pengujian hipotesis secara parsial (uji t) diperoleh nilai thitung sebesar 2,926 dan nilai signifikan sebesar 0,00 , sedangkan nilai $t_{\text {tabel }}$ adalah 1,656. Karena $t_{\text {hitung }}>t_{\text {tabel }}(2,926>$ 1,656) dan nilai signifikan $<0,05(0,00<0,05)$, maka dapat disimpulkan bahwa Motivasi secara parsial berpengaruh positif dan signifikan terhadap kinerja karyawan.

Berdasarkan hasil pengujian hipotesis secara simultan (uji f) diperoleh nilai $f_{\text {hitung }}$ sebesar 13,007 dan nilai signifikan sebesar 0,040 sedangkan nilai $\mathrm{f}_{\text {tabel }}$ pada tingkat kepercayaan adalah 3,12 . Karena $f_{\text {hitung }}>f_{\text {tabel }}(13,007>3,12)$ dan nilai signifikan $<0,05(0,00<0,05)$, maka dapat disimpulkan bahwa variabel Kompensasi dan Motivasi secara bersama-sama berpengaruh positif dan signifikan terhadap kinerja karyawan.

\section{KESIMPULAN}

Dari hasil pembahasan yang telah dilakukan peneliti, maka peneliti memberikan beberapa kesimpulan sebagai berikut:

1. Kompensasi berpengaruh positif dan signfikan terhadap Kinerja Karyawan. Diperoleh nilai thitung sebesar 2,060 dan nilai signifikan sebesar 0,04 , sedangkan nilai $t_{\text {tabel }}$ adalah 1,656. Karena $t_{\text {hitung }}>t_{\text {tabel }}(2,060>$ 1,656) dan nilai signifikan $<0,05(0,04<$ $0,05)$.
2. Motivasi berpengaruh signfikan terhadap Kinerja Karyawan. Diperoleh nilai $t_{\text {hitung }}$ sebesar 2,926 dan nilai signifikan sebesar 0,00 , sedangkan nilai $t_{\text {tabel }}$ adalah 1,656. Karena $t_{\text {hitung }}>t_{\text {tabel }}(2,926>1,656)$ dan nilai signifikan $<0,05(0,00<0,05)$.

3. Kompensasi dan Motivasi secara bersamasama berpengaruh signifikan terhadap Kinerja Karyawan. Diperoleh nilai $f_{\text {hitung }}$ sebesar 13,007 dan nilai signifikan sebesar 0,040 sedangkan nilai $\mathrm{f}_{\text {tabel }}$ pada tingkat kepercayaan adalah 3,12. Karena $\mathrm{f}_{\text {hitung }}>\mathrm{f}_{\text {tabel }}$ $(13,007>3,12)$ dan nilai signifikan $<0,05$ $(0,00<0,05)$, dan berdasarkan uji determinasi (R2) disimpulkan bahwa Kompensasi dan Motivasi mempengaruhi Kinerja Karyawan sebesar 25,8\% sedangkan sisanya sebesar $74,2 \%$ dipengaruhi faktor lain yang tidak digunakan dalam penelitian ini.

\section{DAFTAR RUJUKAN}

Bangun, Wilson. 2012. Manajemen Sumber Daya Manusia. Jakarta: Erlangga.

Burhanuddin.2016.Manajemen SDM untuk Perusahaan. Jakarta: PT Raja Grafindo

Dessler, Gary. 2015. Manajemen Sumber Daya Manusia. Jakarta: Salemba. Empat.

Fahmi, Irham. 2016. Manajemen Sumber Daya Manusia. Yogyakarta: Alfabeta.

Fattah, Hussein. 2015. Kepuasan Kerja dan Kinerja Pegawai. Yogyakarta:Elmatera (Anggota IKAPI).

Handoko, T. Hani. 2014. Manajemen Personalia dan Sumber Daya Manusia. Yogyakarta: BPFE.

Hasibuan, Malayu, S.P, 2014. Manajemen Sumber Daya Manusia, Edisi Revisi, Bumi Aksara, Jakarta

Kartono, Kartini, 2015. Pemimpin dan Kepemimpinan. Jakarta : PT. Raja.

Ma'ruf. Muhammad 2016. Manajemen Komunikasi Periklanan. Yogyakarta: Aswaja Pressindo

Mangkunegara, Anwar Prabu. 2017. Manajemen Sumber Daya Manusia Perusahaan. Bandung: PT Remaja Rosdakarya 
Nawawi. H. Hadari. 2016. Manajemen Sumber Daya Manusia. Cetakan Ketujuh. Yogyakarta : Gadjah Mada University Press

Payaman J. Simanjuntak .2005.Manajemen Evaluasi Kinerja .Edisi $3 . \quad$ Jakarta. Fakutas UI.

Noe, Raymond A., Hollenbeck, John R., Gerhart, Barry, Wright, Patrick M., 2014. Manajemen SumberDaya Manusia : Mencapai Keunggulan Bersaing, Edisi 6 Buku 1, Alih Bahasa : David Wijaya, Jakarta: Salemba Empat

Safroni, Ladzi. 2012. Manajemen dan Reformasi Pelayanan Publik dalam Konteks Birokrasi Indonesia, Surabaya: Aditya Media Publishing.

Samsudin, Sadili. 2010. Manajemen Sumber Daya Manusia. Bandung : Pustaka Setia.

Siagian, 2018, Manajemen Sumber Daya Manusia, Jakarta, PT. Elek Media Kompetindo.

Sinambela Poltak, 2016. Manajemen Sumber Daya Manusia, Jakarta : PT Bumi Aksara

Sudaryono,2014. "Pengantar Bisnis, Teori dan Contoh Kasus." Yogyakarta :Andi

Sudjana, Nana dan Ibrahim.2016.Penelitian Dan Penilaian Pendidikan, Bandung : Sinar Baru Algensindo

Sugiyono, 2016. Metode Penelitian Kuantitatif, Kualitatif dan R\&D, Jakarta: Alfabeta,

Suherman. 2012.Kamus Besar Bahasa Indonesia. Jakarta: Pustaka Pelajar
Sunyoto. Danang S. 2015. Manajemen Sumber Daya Manusia Teori dan Aplikasi. Bandung: ALFABETA.

Tampubolon, Manahan. 2017.Perilaku Organisasi. Jakarta: Ghalia Indonesia

Terry, George 2016. Dasar-Dasar Manajemen. Cetakan kesebelas. PT Bumi Aksara: Jakarta

Thoha, Miftah. 2013. Perilaku Organisasi : Konsep Dasar dan Aplikasinya. Raja Grafindo Persada:.Jakarta

Tohardi, 2015, Pemahaman Praktis Manajemen Sumber Daya Manusia,. Universitas Tanjung Pura, Bandung: Mandar Maju.

Triyono, Ayon. 2012. Paradigma Baru Manajemen Sumber Daya Manusia. Jogjakarta: Oryza

Veithzal Rivai Zainal, Mansyur Ramly, Thoby Mutis, Willy Arafah. 2013. Manajemen Sumber Daya Manusia untuk Perusahaan : dari Teori ke Praktik, Edisi Ketiga, Jakarta: Raja Grafindo Persada

Widodo. Suparno Eko. Manajemen Pengembangan Sumber Daya Manusia. Yogyakarta: Pustaka Pelajar

Wibowo. 2014. Manajemen Kinerja. Edisi keenpat, Jakarta: Rajawali Pers

Wirawan. 2015. Evaluasi Kinerja Sumber Daya Manusia Teori Aplikasi dan Penelitian. Jakarta: Salemba Empat. 